\title{
Strategies for Sustainable Business and Performance in Brazilian Industrial Companies
}

\author{
Clandia Maffini Gomes', Isak Kruglianskas², Flávia Luciane Scherer ${ }^{3}$, Roberto da Luz Neto \\ Jordana Marques Kneippe ${ }^{5}$
}

\begin{abstract}
The study looks to analyze the adoption of strategies for sustainable business and the performance of Brazilian industrial companies. The quantitative character research has involved the execution of a survey. The results have permitted to conclude that the Brazilian companies are enlarging their participation in the international market. However, one must observe that some factors still limit this performance in terms of innovation management and socio-environmental management. Concerning the technological innovation management, one observes that, in spite of the growth of use of external sources of innovation over the last few years, one must still go a long way in the sense of developing a corporate culture that may value the partnership and the collaboration between the companies. Concerning socio-environmental management, the research data confirm the studies by authors mentioned in the literature review who maintain that most Brazilian companies still adopt a reactive stance in relation to these issues.
\end{abstract}

Keywords: strategy; sustainability; performance; brazilian companies; socio-environmental management

Federal University of Santa Maria (UFSM) Av. Roraima, 1000-74C-4I22, Santa Maria/RS, Brazil, 97I05-900

E-mail: 'clandiamg@gmail.com, ${ }^{3}$ flaviascherer@globo.com, ${ }^{4}$ roberlus@yahoo.com.br, ${ }^{5}$ jordanakneipp@yahoo.com.br

${ }^{2}$ São Paulo University (USP), Luciano Gualberto 908, São Paulo-SP, Brazil, 05508, ikruglia@gmail.com.

School of Economics, Business and Accounting (FEA) of University of São Paulo (USP), Brazil.

ISSN: 07 I8-2724. (http://www.jotmi.org)

Journal of Technology Management \& Innovation (c) Universidad Alberto Hurtado, Facultad de Economía y Negocios. 


\section{Introduction}

The development of a sustainable technological innovation model constitutes one of the main corporate challenges of the millennium: how to innovate in a sustainable way and enlarge competitiveness on global markets, complying with international requirements and regulations?

With the technological development, the giant enlargement of the production resources, the evolution of machines and tools, other aspects of the influence of industrial activity have started to be questioned, as the environmental care issue and the social benefits. At the same time, international organisms, the evolution of environmental control methods, the internationalization of activities and the universalization of labor rights and the sustainable development ideal have started to establish minimum rules or parameters so that a company can operate in a given activity or region. The media undertakes the divulging to the public opinion of activities that may be considered socially and environmentally irresponsible, causing many times significant prejudices to the company's image. The socially responsible performance does not imply that the corporate management may abandon its economic objectives and fail to meet the interests of its owners and shareholders; on the contrary, a company is socially responsible if it plays a social role at the community by producing assets and services, generating jobs, return to the shareholders within the legal and ethic standards of society. (BORGER, 200I).

From these presuppositions, the study looks to analyze the impact of the adoption of sustainable business strategies on the performance of Brazilian industrial companies. The conclusions of the study must confirm the development of a world-class management excellence model aligned with the international demands that may guarantee the entry and maintenance of Brazilian industrial companies in the world scenario.

The study has as objective to identify the main sustainable business strategies and the main indicators that make up the corporate performance of the researched companies.

The company management for sustainable development constitutes an emerging theme in the academic and company environment. The Brazilian companies lack studies adapted to their reality, with methodologies and practices that may respond to specific issues of their operation context, since one has much about the context of other countries, mainly the most developed.

The analysis of sustainable business strategies at Brazilian industrial companies has as objective to understand the main aspects that influence the behavior of companies concern- ing themes of recognized strategic importance for Brazil at the economic and technological moment in force. The public policies directed to the increase of exports and the insertion of the Brazilian companies into the international context justify more and more the existence of studies and researches of this nature.

\section{Theoretical references}

\section{Sustainable strategies for innovation and competitiveness}

The concern about the environmental preservation has conquered a discussion space within the agenda of governments, organizations, and society itself. According to Coimbra (1985), environment is the set of the physico-chemical elements, natural and social eco-system into which Man inserts himself, individually and socially, in an interaction process that may meet the development of human activities, the preservation of the natural resources and the essential characteristics of the surroundings, within defined quality standards.

The growing insertion of this issue into the trade relations makes to emerge a new concept of management that incorporates the environmental variable in search of greater quantitative and qualitative efficiency of the production system (POUSA, Monteiro, Renovato, Ribeiro, And Scarpim, 2007).

This debate has its origin with the original concept of Sustainable Development, proposed by the World Commission for Development and Environment - Brundtland Commission - in 1987. This commission considers technically feasible to provide for minimum needs for the double of the world population, in a sustainable way and without continuing degradation of the global eco-system, in order to "meet the needs of the present generation without compromising the skill of future generations to meet their own needs". (AMARAL and Rovere, 2003).

The global competition has started to demand efforts on the part of the countries in order to go on competitive in the long run. One has started to demand at companies, also, greater efforts in various areas. Among these areas, the environment and the sustained development deserve to be highlighted for being related to the processes of knowledge, $R \& D$, besides contributing to the environment of business under the form of new opportunities of products and services. In this context, the importance of the treatment of socio-environmental and technological issues for the Brazilian companies in a trans-nationalization process is fundamental (FRESCURA, 2007).

ISSN: 07 I8-2724. (http://www.jotmi.org)

Journal of Technology Management \& Innovation (c) Universidad Alberto Hurtado, Facultad de Economía y Negocios. 
The product system incorporates the aspects and impacts into the process of raw material extraction , transport, processing, transport for manufacturing. At the industrial consumer, one considers the product design and the characteristics of the production process, distribution, consumption, disposal and destination of packagings, and remains from the product at the end of its life cycle. (FURTADO, 2003).

An innovation process can originate itself in different sectors, external and internal to the organization. New ideas can be originated from different sources. One highlights, among them, the suppliers, the clients, the competitors, the companies from other sectors, the company's employees, the works produced at other institutions, as universities and I or research centers. On the other hand, the way the company gets in contact with these sources and is stimulated to formulate new ideas is very varied: internal inspiration from one or more people, contacts with external organizations, offers from technology licensors, visits to fairs, participation in seminars and events, exchange at company (or even social) associations, technical and mercadological publications. (KRUGLIANSKAS, I., 1996).

Many competitive strategies have been developed from the sustainable development theories. However, few of them focus on the innovation of the projects, one of the most important elements for their implementation. And, moreover, it becomes necessary to consider the need of alignment of the competitive strategies with the three dimensions of sustainable development: the economic, social, and environmental aspects (ETHOS, 2006).

The conceptual model developed by BERGER (200I) highlights the performance oriented to the corporate social responsibility (RSE) and the Corporate Dynamics. In the multi-case study developed at companies representing the Brazilian industry, the social performance of the company is understood as the set of initiatives and actions directed to the construction of relations with the social agents which are affected by their activities and which characterize the engagement in the RSE. The main variable highlighted in the study can be observed in figure I.

The economic performance is associated to the competitiveness of the companies, achieved when a company successfully formulates and implements a strategy that creates value, in a way that the other companies cannot replicate its results, and propitiates a return above average to the investors, so that these may keep the provision of resources for the business. The management of the business involves the decision and analysis, the risks involved and the impacts of the business on society. The economic approach has forced the corporation to continuingly improve their financial performance, obeying the regulations of the markets. At the same time, consumers in most international markets are demanding products and services with better quality and consistent with the environmental and social values. These requirements compete to simultaneously improve the financial, social, and environmental performance and encourage the companies to look for innovative ways to relate with the social environment. This stance leads them to adopt strategies to increment their reputation. (BERGER, 200I).

Reputation is a series of perceptions by people in and out of the company. The reputation of a company results from: credibility, integrity, reliability, and responsibility (Miles-Govin, 2000, quoted by Berger, 200I). A superior corporate reputation is an intangible asset and a source of strategic advantage, increasing the capacity of a corporation to create value in the long run, being a contribution for the global performance of the companies.

In this same theoretical line it is convenient to highlight the study about socio-environmental responsibility developed

\begin{tabular}{|l|l|}
\hline Engagement in RSE & Corporate Dynamics \\
\hline $\begin{array}{l}\text { Leadership and Commitment (inclusion of the RSE } \\
\text { principles in the Mission, Company's Values, Top } \\
\begin{array}{l}\text { Management's Involvement, RSE Function in the } \\
\text { Structure, Participation in Social, Company Entities). }\end{array}\end{array}$ & $\begin{array}{l}\text { I. Organizational Climate (Satisfaction, Productivity, Attraction, } \\
\text { and Retention of Employees, Employees' Training) }\end{array}$ \\
\hline $\begin{array}{l}\text { Policies and Strategies (General and Sectorial Policy, } \\
\text { Inclusion of RSE in the Sectorial General Strategy) }\end{array}$ & $\begin{array}{l}\text { 2. Technological Performance (Agility, Flexibility, Innovation Ca- } \\
\text { pacity) }\end{array}$ \\
\hline $\begin{array}{l}\text { Processes and Procedures (Formal Systems, Train- } \\
\text { ing, Assessment, Communication) }\end{array}$ & $\begin{array}{l}\text { 3. Operational, Economic-Financial, and Mercadological Per- } \\
\text { formance (Environmental Economic Performance and Market } \\
\text { Share). }\end{array}$ \\
\hline (social and environmental) Projects and Actions & 4. Reputation (Institutional Image) \\
\hline
\end{tabular}

Figure I - Corporate social responsibility (RSE) and the Corporate Dynamics. Source: BERGER (200I)

ISSN: 07 I8-2724. (http://www.jotmi.org)

Journal of Technology Management \& Innovation @ Universidad Alberto Hurtado, Facultad de Economía y Negocios. 
by Kruglianskas, M. (2008) at Brazilian industrial companies. This conceptual model has been developed to understand how the activities for managing the corporate socio-environmental responsibility relate themselves with reputation; how reputation is related to the economic and financial performance and how the management of the company's communication with its stakeholders influences the relationship, as one can observe in figure 2 .

Among the conclusions of the study one can mention the existence of few empiric studies related to the corporate socio-environmental responsibility, reputation, economic performance, and communication management. The study has also highlighted the increment of publications related to the theme of corporate socio-environmental responsibility and of reputation over the last few years. However, the inclusion of the communication management is still little made.

The theme of socio-environmental responsibility takes on an ever greater dimension in our relating this variable to the internationalization process of the companies.

\section{The socio-environmental management and the international insertion}

The corporate socio-environmental responsibility is a continuing and progressive process of involvement and development of citizen competences of the company, with the discussion of social and environmental issues related to all the audiences with which it interacts: the body of direct collaborators (internal audience), partners and shareholders, suppliers, clients and consumers, market and competitors, public powers, press, community, and the environment itself. The origin of the concept reaches back to the end of the 60 's, with the insurgence of social movements that started to put pressure on the big companies, demanding they respond for the direct consequences of their activities. In the following years, in the 70's and 80's, there occur the birth and strengthening of several organized groups of civil society. In this same period, one verifies the intensification of the trans-nationalization process of several companies, causing significant cultural impacts and conflicts in several countries. Over the last few years, there has been an increase in the pressure for the companies to respond for socio-environmental issues. (GASPAR, 2006).

In commenting on the evolution of the environmental strategy, Polizelli, Petroni, and Kruglianskas, I. (2005), highlight the role of OECD and the European Union. These institutions have elaborated a broad strategy for the development of the socio-environmental management. First, one has oriented the environmental policies complementary to the economic development and to the fostering of environmental business, changing the vision of the companies in relation to the legislation and serving as stimulus to the innovative technologies. Next, in the 1990's, one emphasized the technologies directed to the sustainable development, proposing the systemic innovation for integration of efforts of R\&D

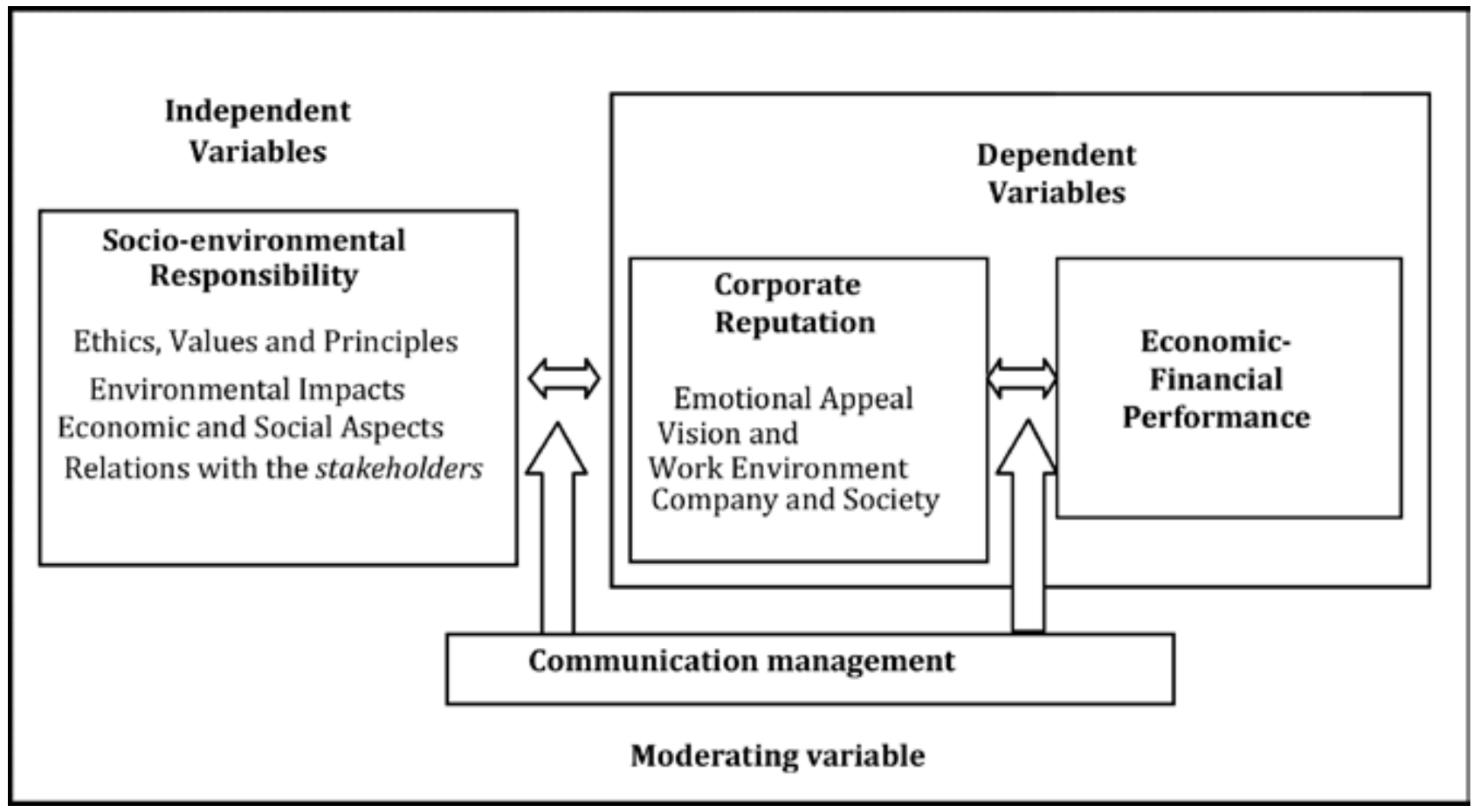

Figure 2 - Socio-Environmental Responsibility, Corporate Reputation, and Performance. Source: Kruglianskas, M., 2008

ISSN: 07 I 8-2724. (http://www.jotmi.org)

Journal of Technology Management \& Innovation (c) Universidad Alberto Hurtado, Facultad de Economía y Negocios. 
for the reduction of costs and increase in the speed of the innovation processes. The environment has become an important market. In a later phase, the environmental management starts to be understood in a broader scenario related to the environmental policies. This period reinforces the integration of efforts between residences, companies, and government. The knowledge from the improvement of the business network starts to be the fundamental issue. Finally, from the year 200I, one has made explicit the role of informatics and communication technologies aiming to foster the efficient use of energy, monitor the resources and costs in the intra-company cooperation networks to decrease the environmental impacts. There appear four new paradigms of environmental management: command and control; market instruments; hybrid approaches; and knowledge management.

In relation to the assessment and certification process, the standards are the basis of certification and define what the product or production process must contain or achieve to be certified. The main environmental certification movements - organic agriculture, agricultural socio-environmental FSC, and ISO 14.000 - have created the figure of the accreditor (IFOAM, FSC, and ISO respectively). The accreditor is the entity that regulates the functioning of the certification, defines the manner of application of the standards, and inspects the accreditors' activity.

The characterization of the Environmental Management Paradigms (PGA) involves, besides the OCDE's documents, other contributions. The first of them refers to the environmental marketing that provides ground to the PGAs in various moments. The growth of the ecologic sensitiveness has had its start directed only to the improvement of the image through localized actions like the case of the packagings and of actions directed to the environmental protection in the institutional plan. The consumer's sensitiveness used to be located out of the focus of the company's business, displaced form the investment in R\&D, in products and services. In the 90's, the companies evolved to the concept of ecologic marketing with explicit environmental commitments to the clients and society through the design, production, post-sale, and final disposal (PINTO and PRADA, 1999).

The development of the urban and industrial society, for not knowing limits, has occurred in a disordered way, without planning, at the cost of growing levels of pollution and environmental degradation. Hence the negative impacts on the quality of the air and on human health in big cities (BRAGA, 2002). Technology contributes to revert some situations and advance, estimatively, future hypothetical situations, permitting to recognize that there are limits to be respected, many times unknown.
The concern about the climatic changes forms part of the conferences and official commitments of governments and development bodies at a global level. The adaptation to change the impact of climate will be essential, especially in the poorest areas of the world. The sustainable development is the key of adaptation from the development of good practices and of the reduction of vulnerability: promotion of growth, diversification of the economic activity, investment in health and education, enlargement of the mechanisms for overcoming and improving the management of disasters and the promotion of the association-risk, including the social security networks for the poorest one. In the developed countries, much adaptation will be a local response by individuals to a changing climate.The communities and the companies respond in an independent way to the climate change and to the extreme variability in a way to help reduce the harmful effects. However, these independent responses are distant from what it takes, given the current vulnerabilities and the scale of future impacts. The governments will have as an essential role to reduce this vulnerability with the good practice of development, including the best practices for management of risks of disaster and use of social security networks to protect the most vulnerable. (STERN, 2007)

In dealing with organization, an issue that has been frequently raised in the corporate and academic milieux when it comes to broaching the theme of investment in sustainability is the return that it will bring to the business. To respond to this inquiry, it is important to remember that there are two indices that present the evolution of the value of the actions at the financial market of companies that privilege the investment in social responsibility and sustainable development (ARANTES, 2006).

The sustainability model could avoid abuses in the exploration and consumption of the natural resources. A sustainable economy could continue to develop, but with some adaptations from advancements in technical and scientific knowledge of the organizational systems and of the efficiency of its processes (MALHADAS, 200I).

This way, the future economic growth will need to occur within the physical limits of the environment, being necessary changes in the structures of the industrial economies. These changes will concentrate themselves on the direction of seeking the most efficient use of energy and resources, in non-polluting production processes, in the reduction of residues and emissions and in the management of technological risks (BRAGA, 2002).

This could be carried out through an Environmental Management program of a sustainable organization project worked and discussed between nations. The Environmental Management aims to limit the damages to the environment

ISSN: 07 I8-2724. (http://www.jotmi.org)

Journal of Technology Management \& Innovation (c) Universidad Alberto Hurtado, Facultad de Economía y Negocios. 
caused by the industrial activities. The sustainable organization project looks to create organizations with a systemic, global, comprising, and holistic vision (ANDRADE, 2000).

Various are the grounds and reasons that compel the organization to the adoption and practice of the environmental management, being able to result from mandatory procedures of compliance with the environmental legislation to the fixation of environmental policies that may aim at the awareness of all the personnel of the organization and of the social milieu that surrounds it. The Environmental Management systems are useful for the managers to check how much an environmentally correct stance in the management of its processes directly reflects on productivity, quality and, consequently, better economic financial results even through the valorization of the company's image before society (POUSA, Monteiro, Renovato, Ribeiro, And Scarpim, 2007).

On new international markets, international strategic alliances are established in a way that a partner typically brings products or services (as resources) to an alliance and the other partner brings local knowledge, local distribution networks, and political influence to the relation. Some types of incentives for cooperating in strategic alliances exist only when partner companies have similar strategic targets and objectives. Moreover, for the fact that they are socially complex and based on strong trust relations (CHILD and FAULKNER, 1998), they can be of difficult imitation and, for this reason, constitute a source of sustainable competitive advantage.

In general, the companies inserted in the global markets and wishing to grow and develop themselves must promote a deep reflection in its structural organization, starting by the revision of its mission in the face of the new reality of the markets. This new mission must contemplate the needs of the markets and the way to serve them (KEEGAN and GREEN, 1999).

The adoption of sustainable strategies in the corporate practice aiming to face the challenges of the millennium becomes fundamental for the economic development and the conservation and maintenance of the available natural resources.

\section{Methodology}

\section{Research method}

The research has characterized itself as a quantitative nature investigation. According to Babbie (1999), the survey studies are carried out to allow for descriptive enunciates about a population.

In the quantitative research, which involves the execution of a survey, one has adopted a conceptual model relating the variables that make up the management for the sustainable development and the corporate performance. For this, one has applied a data collection instrument, made up of closed questions, at Brazilian industrial companies, aiming to identify how the adoption of sustainable strategies influences their competitiveness.

A socially responsible management strategy substantially contributes to the development of the corporate performance. The sustainable strategic management performance is oriented to economic, social, and environmental results for the organization and its stakeholders.

As follows one details the procedures utilized for obtaining and analyzing data in order to prove the research presupposition.

\section{Analysis dimensions}

For effects of operationalization of the conceptual model adopted, the independent, dependent, and moderating variables have been defined and categorized in analysis groups which are described as follows, in figures 3 and 4 .

\section{Sustainable management strategies and practices}

\section{Socio-Environmental Responsibility}

Social: Expenditure on the restaurant, food vouchers, snacks, basic food parcels and / or others related to the employees' nourishment; special plans for retired people, social security foundations and / or benefit complements for retired people and their dependants; health plans, medical care, preventive medicine programs, quality of life programs and / or other expenditure on health, including the one of retired people; expenditure on regular teaching at all levels, education refund, scholarships, magazine subscriptions, expenditure on libraries and other expenditure on education are the company's attitude; expenditure on artistic and cultural events and manifestations (music, theater, cinema, literature, and other art); nursery at the company and / or nursery aid to collaborators.

Environmental: The company is seen as being administered in an adequate way; the external milieu considers that it's an opportunity working at the company; at the external milieu there is a perception that the level of qualification of the company's employees is very, very high; the perception is the one that the company is among those which offer the best material working conditions to its employees; monitoring of the quality of residues/effluents, de-pollution program/project, or spends on the introductions of non-polluting methods, Environmental audits, Environmental education pro-

ISSN: 07 I8-2724. (http://www.jotmi.org)

Journal of Technology Management \& Innovation () Universidad Alberto Hurtado, Facultad de Economía y Negocios. 
grams for the employees, Other expenditure with the aim of incrementing and seeking the continuing improvement of the environmental quality in the production/operation of the company, Ecological campaigns and socio-environmental education for the external community and for the society in general, Environmental goals established by the organization itself, by civil society organizations and / or by international parameters. The company manages the environmental impacts caused by it, Insertion of the company into an ISO I 400 I certification system and / or other equivalent ones.

\section{Socio-environmental Responsibility}

Social: Expenditure on the restaurant, food vouchers, snacks, basic food parcels and / or others related to the employees' nourishment; special plans for retired people, social security foundations and / or benefit complements for retired people and their dependants; health plans, medical care, preventive medicine programs, quality of life programs and / or other expenditure on health, including the one of retired people; expenditure on regular teaching at all levels, education refund, scholarship, magazine subscriptions, expenditure on libraries and other expenditure on education are the company's attitude; expenditure on artistic and cultural events and manifestations (music, theater, cinema, literature, and other art); nursery at the company and / or nursery aid to collaborators.

Environmental: The company is seen as being administered in an adequate way; the external milieu considers that it's an opportunity working at the company; in the external milieu there is a perception that the level of qualification of the companies' employees is very, very high; the perception is the one that the company is among those which offer the best material working conditions to its employees; monitoring of the quality of the residues / effluents, de-pollution program / project, or expenditure on the introduction of non-polluting methods, Environmental audits, Environmental education programs for the employees, Other expenditure with the objective of incrementing and seeking the continuing improvement of the environmental quality in the company's production / operation, Ecological campaigns and socioenvironmental education for the external community and for the society in general, Environmental goals established by the organization itself, by civil society organizations and / or by international parameters. The company manages the environmental impacts caused by it, Insertion of the company into an ISO I400I certification program and / or in other equivalent ones.

\section{Socio-environmental Reputation and Image}

Socio-environmental Reputation / Image: The media in general projects the company as an unconditional supporter of the good socio-environmental causes. The audience considers that the company acts in a highly responsible way in relation to the defense of the community's interests. The company's score in published rankings and / or indices that monitor the initiatives of Corporate Social Responsibility is very high. In the perception of the market the social responsibility performance of the company is authentic (not only of corporate marketing)

\section{Corporate performance}

Environmental impacts: Management practices of environmental impacts; Concern about introducing improvement in the products (assets and / or services) to reduce in a systematic way their negative environmental impacts; Search for improvement with a view to reducing / eliminating their negative impacts from the productive processes in the environment; Management procedures known by the employees to minimize negative risks of environmental impacts are fully. Economic impacts: The financial performance indicators of the accounting balance sheets position the company among the best of the sector. The financial market considers the return on investments in shares of the company as highly attractive. The company is perceived on the market as a lowrisk investment for the shareholders. The company is included in lists of investment funds of companies considered as socially responsible (Ethic Funds)

Social impacts: The company supports the development of the local community by prioritizing local suppliers; Support to the development of the local community through the prioritization in hiring local personnel. Socially and / or economically support the neediest segments of the community.

\section{International insertion}

International insertion: the degree of international insertion is characterized in the research, according to the percentage resulting from its international operations, considering the company's gross operational revenue (2008).

\section{Research universe and Sample composition}

The research universe has been constituted by Brazilian companies of the industrial sector with characteristics and hints of emphasis on the innovation activity. The choice of this population as an object of investigation has attached itself to the fact that it is in the type of company that occurs, in a more emphatic way, the concern about technological innovation and, consequently, the search for adequacy to the socio-environmental norms and demands.

The register base of the companies invited to take part in the research has been the list of companies linked to the

ISSN: 07 I8-2724. (http://www.jotmi.org)

Journal of Technology Management \& Innovation (c) Universidad Alberto Hurtado, Facultad de Economía y Negocios. 
Sustainable management strategies and practices

Socio-Environmental Responsibility

Social: Expenditure on the restaurant, food vouchers, snacks, basic food parcels and / or others related to the employees' nourishment; special plans for retired people, social security foundations and / or benefit complements for retired people and their dependants; health plans, medical care, preventive medicine programs, quality of life programs and / or other expenditure on health, including the one of retired people; expenditure on regular teaching at all levels, education refund, scholarships, magazine subscriptions, expenditure on libraries and other expenditure on education are the company's attitude; expenditure on artistic and cultural events and manifestations (music, theater, cinema, literature, and other art); nursery at the company and / or nursery aid to collaborators.

Environmental:The company is seen as being administered in an adequate way; the external milieu considers that it's an opportunity working at the company; at the external milieu there is a perception that the level of qualification of the company's employees is very, very high; the perception is the one that the company is among those which offer the best material working conditions to its employees; monitoring of the quality of residues/effluents, de-pollution program/project, or spends on the introductions of non-polluting methods, Environmental audits, Environmental education programs for the employees, Other expenditure with the aim of incrementing and seeking the continuing improvement of the environmental quality in the production/operation of the company, Ecological campaigns and socio-environmental education for the external community and for the society in general, Environmental goals established by the organization itself, by civil society organizations and / or by international parameters. The company manages the environmental impacts caused by it, Insertion of the company into an ISO I400I certification system and / or other equivalent ones.

Socio-environmental Responsibility

Social: Expenditure on the restaurant, food vouchers, snacks, basic food parcels and / or others related to the employees' nourishment; special plans for retired people, social security foundations and / or benefit complements for retired people and their dependants; health plans, medical care, preventive medicine programs, quality of life programs and / or other expenditure on health, including the one of retired people; expenditure on regular teaching at all levels, education refund, scholarship, magazine subscriptions, expenditure on libraries and other expenditure on education are the company's attitude; expenditure on artistic and cultural events and manifestations (music, theater, cinema, literature, and other art); nursery at the company and / or nursery aid to collaborators.

Environmental:The company is seen as being administered in an adequate way; the external milieu considers that it's an opportunity working at the company; in the external milieu there is a perception that the level of qualification of the companies' employees is very, very high; the perception is the one that the company is among those which offer the best material working conditions to its employees; monitoring of the quality of the residues / effluents, de-pollution program / project, or expenditure on the introduction of non-polluting methods, Environmental audits, Environmental education programs for the employees, Other expenditure with the objective of incrementing and seeking the continuing improvement of the environmental quality in the company's production / operation, Ecological campaigns and socio-environmental education for the external community and for the society in general, Environmental goals established by the organization itself, by civil society organizations and / or by international parameters. The company manages the environmental impacts caused by it, Insertion of the company into an ISO I400 I certification program and / or in other equivalent ones.

Socio-environmental Reputation and Image

Socio-environmental Reputation / Image:The media in general projects the company as an unconditional supporter of the good socio-environmental causes. The audience considers that the company acts in a highly responsible way in relation to the defense of the community's interests. The company's score in published rankings and / or indices that monitor the initiatives of Corporate Social Responsibility is very high. In the perception of the market the social responsibility performance of the company is authentic (not only of corporate marketing)

Figure 3 - Sustainable management strategies and practices. Source: IBASE (2009); Berger, (200I) and Kruglianskas, M. (2008)

National Associaton for Research, Development, and Engineering of the Innovative Companies [ANPEI]. The register of companies available in the database of ANPEl counts on 96 national companies of the industrial and services sector related to the technological innovation activity.

By virtue of the objectives of the research, the research register base has been reduced to 93 companies, restricting the sample only to the companies with industrial or transformation activity. One has excluded, therefore, the companies that operate exclusively with the rendering of consultancy services in the areas of technological support and legislation.

\section{Procedures for data collection and analysis}

The questionnaire has been directed to the person responsible for the technology area, directors or presidents of the companies. The form of sending of the data collection instrument has been direct mailing by means of email and the phone contact. The procedures adopted for the data collection, the instrument structure analysis and the description of the application plan for the data collection are discussed as follows. 
Corporate performance

Environmental impacts: Management practices of environmental impacts; Concern about introducing improvement in the products (assets and / or services) to reduce in a systematic way their negative environmental impacts; Search for improvement with a view to reducing / eliminating their negative impacts from the productive processes in the environment; Management procedures known by the employees to minimize negative risks of environmental impacts are fully.

Economic impacts: The financial performance indicators of the accounting balance sheets position the company among the best of the sector. The financial market considers the return on investments in shares of the company as highly attractive. The company is perceived on the market as a low-risk investment for the shareholders. The company is included in lists of investment funds of companies considered as socially responsible (Ethic Funds)

Social impacts: The company supports the development of the local community by prioritizing local suppliers; Support to the development of the local community through the prioritization in hiring local personnel. Socially and / or economically support the neediest segments of the community

International insertion

International insertion: the degree of international insertion is characterized in the research, according to the percentage resulting from its international operations, considering the company's gross operational revenue (2008).

Figure 4 - Corporate performance. Source: GRI (2009)

The questionnaire has been directed to the persons responsible for the technology area, directors or presidents of the companies linked to ANPEI. The form of sending of the data collection instrument utilized has been through the Internet by means of email.

The data collection has been carried out during 90 days (October to December, 2009). In this period, besides the contact via email, one has utilized the phone contact with the companies, aiming at the greater number of responses, enlarging the representativeness of the sample.

The total of responses obtained has been elevated considering the register base utilized. Out of a total of 93 companies, 45 questionnaires have been received, around $48 \%$. A response index above $25 \%$ is considered elevated for most specialists. One must also consider the difficulties in obtaining information from a group of companies, highlighting the area of technological innovation, in which the issues of secret agreements are very common. Sum to that the implications and the existence of issues related to the companies' performance, information many times delicate in sectors with a high degree of competitiveness.

One can observe, according to the data presented, that the response index in the researched group has been elevated. This is explained, fundamentally, by the fact that the group of companies linked to ANPEI constitutes a group with a focus on the innovation activity and with an interest in the benchmark of the research results. This interest has been explicitly manifested by the respondents of the research through phone contacts and via email.
The data have been processed with the aid of Excel and SPSS software. The analysis of the data has been carried out in a univariate way.

The exploratory analysis of the data has been carried out in a descriptive manner, from the verification of the central tendency measures, which permits to identify the main frequencies observed in relation to a given variable.

\section{Analysis of results}

On the basis of the data obtained through the survey-like research, one moves on, now, to the processing of the analysis, initially, of the characteristics that constitute the profile of the respondents and of the companies that make up the sample. Next are presented the values taken on by the variables. The analyses are carried out in a univariate manner looking to apprehend specific details of the data as well as to obtain an integrated vision of the independent and dependent variables.

Most companies characterize themselves as big-sized (in number of employees and revenue) and concentrate on sectors of elevated technological sophistication. The group of companies presents, therefore, an attractive profile for the identification of the characteristics to which the study proposes itself.

It becomes important to highlight the evolution of the participation of exports in the gross operational revenue, if we compare the data obtained in this research (between 10 and $70 \%$ ) in relation to the data of the research carried out with the same group of companies in 2006 (up to 10\%), according to GOMES (2007). These data can evidence a significant evolution in the process of internationalization of the researched group of companies. 


\section{International performance}

The companies' performance abroad is assessed through the analysis of the variables: start of internationalization of the company's business, the company's number of employees, on average, abroad, the main strategy utilized by the company on the international markets it operates on, the existence of subsidiaries abroad and the operation countries, the reasons that explain the going of the company to the external market and the reach of the goals for the external market.

The analysis of the internationalization process starting period evidences that, out of the companies that have internationalized their business (around 50\%), a part of them has been mature in business operating in the international scenario for several decades (18\%). What calls the attention is the fact that a significant portion of these companies has started their internationalization process from the 80's $(18 \%)$ and from $200 \mathrm{I}(18 \%)$, an aspect that points to an effective potentialization of the internationalization process of the Brazilian companies over the last decade.

The number of Brazilian and foreign employees of the Brazilian companies abroad is not significant (most companies have between 10 and 400 employees). This is probably justified by virtue of the strategies utilized for performance abroad, operating in export activities by means of intermediaries. Only a portion of the companies choose strategies that involve the fixation of international operation bases involving greater spending on human and financial resources. In addition, one must highlight that the adoption of partnership mechanisms for operation in other countries, like the joint venture, is little utilized. The main form of operation abroad is as the only owner of the subsidiary.

Among the researched companies which have international operations, only $46 \%$ have subsidiaries abroad. The subsidiaries are located mainly in the USA, South and Central American countries, Europe and Asia.

One observes, also, the companies' preference for more conventional and secure strategies for operation abroad, like export with or without intermediation.

The search for opportunities on new markets, for diversification of the business and of technological innovations, is the main aspect that influences the decision to operate on international markets. The increase in market share and the positioning are the main goals of companies that justify their operation abroad.

\section{Socio-environmental management}

The socio-environmental management is assessed in relation to the social investment, work environment, environmental investment, and the socio-environmental reputation of the researched companies.

The social investments are, in general, of medium and high intensity, in the analyzed group of the companies that have responded to the formulated questions, revealing an elevated level of commitment to the adoption of practices of this nature. It is possible to observe, on the basis of the data presented, that the biggest social investments are located in basic issues like nourishment, training, and family assistance. One must highlight the elevated percentage of non-responses, which may indicate that the social issues are not yet considered by some companies as an investment, even in a group of high-profile companies in the national scenario.

The company's image in relation to its work environment is assessed as of elevated intensity.

Most investments of environmental origin, according to data on table 6 , are in the issues related to the management of environmental impacts like the monitoring of the quality of residues / effluents, de-pollution program / project, introduction of non-polluting methods, environmental audits, and insertion of the company into an ISO I400I certification system and / or other equivalent ones.

The data evidence that the reputation of the companies in relation to their socio-environmental performance is, in general, favorable. Although one can observe a greater investment in aspects of environmental order in relation to the social investment, the stance of the companies in relation to both aspects still seems to be excessively shy and directed to interests of operational and regulatory basic origin.

In general, the results lead to the understanding that the behavior of the analyzed companies, concerning the adoption of socio-environmental practices, can be considered as still incipient and concentrating prioritarily in basic and regulatory aspects.

\section{Corporate Performance}

The results of the innovation activity are measured by means of the intensity assessment of the impacts on the innovation activity and of the evolution of the performance indicators over the last five years.

The enlargement of the range of products offered constitutes the main contribution of the innovation activity identified by the companies. Next, one has considered as important the contributions related to the improvement in the quality of

ISSN: 07 I8-2724. (http://www.jotmi.org)

Journal of Technology Management \& Innovation (c) Universidad Alberto Hurtado, Facultad de Economía y Negocios. 
the products, enlargement of the company's participation in the market, reduction of the environmental impact, to the increase of the production capacity, to the reduction of the production costs, to the entry into new markets.

The results lead to the understanding that the main concern of the companies resides on the search for increase in participation and the competitiveness on the market.

The improvement in aspects associated to the regulations and norms of the internal and external market as well as in aspects associated to security or health and to the improvement of the production flexibility constitutes other benefits considered as highly important for the companies. This is due, probably, to the fact that the observation and the compliance with the regulations and norms are aspects that limit the competitiveness of the companies in the national and international scenarios.

One highlights that the reduction of the environmental impact is a valued aspect by the companies, which may mean that the companies consider as strategically important the minimization of the environmental impact of the productive and technological activity on the current and future competitiveness of the companies.

The concern about the minimization of the environmental risks and impacts constitutes the main concern of the companies. This verification confirms the vision of most authors of the consulted literature, who maintain that the approach of most companies still concentrates itself on regulatory aspects. The corporate vision related to the attempt to add value to the product through the investment in environmental aspects constitutes a vision to be developed by the companies in general.

The main impacts considered by the companies are the leadership and the competitiveness in the sector. In addition, one highlights the support to the local community, prioritizing the hiring of employees of the local community.

The total number of upper-level technicians linked to the company constitutes the indicator that has presented a greater evolution index in the period considered. These data suggest that the companies may be enlarging their capacity of innovation in products and process. On the other hand, it may indicate, also, a greater ease on the part of the companies in assessing the evolution of these indicators.

At the same time, the evolution of the number of patents in Brazil and abroad over the last five years has been considered from average to very low. These data may mean that, in spite of the presence of hints of competitiveness enlargement, the companies do not invest in the registration of patents due to cultural and legislation factors.

\section{Final Considerations}

The univariate analyses have permitted to conclude, confirming the theoretical presuppositions that a great part of the researched Brazilian companies is in a business internationalization phase, especially as of the last few years. The international performance characterizes itself by the adoption of conservative forms, with intermediation and low investment in foreign structures to minimize the risk and the cost. A significant portion of these companies started their internationalization process recently, an aspect that points to an effective potentialization of the internationalization process of the Brazilian companies over the last few years. The search for opportunities on new markets, diversification of business and technological innovations are the main aspects that influence the decision of performing on international markets. The growth of the market share and the positioning are the main goals of the companies that justify their performance abroad.

The behavior of the companies in relation to the types of sources of technological information utilized by the companies leads to the understanding that the most utilized internal sources of information by the companies are, with greater highlight, the R\&D department, followed by other departments of the company. As follows, highlighted by the high intensity of use are the clients, fairs, and exhibitions, technical and scientific publications, network, suppliers, and upper education universities/centers. One verifies a tendency for the greater utilization on the part of the researched companies of internal sources, presenting, at the same time, a tendency to the increase in the use of external sources of technological information.

The factors that make the partnership management difficult are of internal origin, related to the work infrastructure and to the interaction with the partners. One verifies the little structure and preparation of the companies in the management due to the displacement of the focus from the internal information to the information external to the company, where the management of the relationship between the partners becomes a successful conditionant of the innovation activity.

The social investments are, in general, of medium and high intensity, in the analyzed group of companies, revealing an elevated level of commitment with the adoption of practices of this nature. The biggest social investments are located in basic issues like nourishment, training, and family assistance. Although one can observe a greater investment in aspects of environmental order in relation to the social investment, the stance of the companies in relation to both aspects still seems to be excessively shy and directed to interests of operational and regulatory basic origin. The behavior of the

ISSN: 07 I8-2724. (http://www.jotmi.org)

Journal of Technology Management \& Innovation (c) Universidad Alberto Hurtado, Facultad de Economía y Negocios. 
analyzed companies, concerning the adoption of socio-environmental practices, can be considered as still incipient and concentrating prioritarily on basic and regulatory aspects.

The reduction of the environmental impact is an aspect valued by the companies, which can mean that the companies consider strategically important the minimization of the environmental impact of the productive and technological activity on the current and future competitiveness of the companies.

The concern about the minimization of environmental risks and impacts constitutes the main concern of companies. This verification confirms the vision of most authors of the consulted literature, who maintain that most companies still concentrate themselves on regulatory aspects. The corporate vision related to the attempt to add value to the product through investments in environmental aspects constitutes a vision to be developed by the companies in general. It is possible to conclude that the Brazilian companies are enlarging their participation in the international market. However, one must observe that some factors still limit this performance in terms of innovation management and socioenvironmental management. Concerning the management of technological innovation, one observes that, in spite of the growth of use of external sources of innovation over the last few years, one must still go a long way in the sense of developing a corporate culture that may value the partnership and collaboration between companies. In addition to the culture, the structures of the companies must be worked to favor the management of projects in partnership. The public power is another important articulation element that must develop itself in the sense of favoring the generation and potentialization of these processes.

Concerning socio-environmental management, the research data confirm the studies by authors mentioned in the literature review which maintain that most Brazilian companies still adopts a reactive stance in relation to these issues, basically fixing themselves on investments and regulatory actions to meet the requirements and demands of national and international standards.

A significant change is necessary in the corporate stance for the achievement of a greater corporate competitiveness. This goes through the understanding that investments in innovation, committed to sustainable actions, constitute a concrete way to add value to the national product and overcome the barriers and conditionants of the international performance and competitiveness.

\section{References}

AMARAL, S. P.;La Rovere, E. L. (2003). Indicators to evaluate environmental, social and economic sustainability: a proposal for the Brazilian oil industry. Oil \& Gas Journal. Tulsa, May, I0I, 30-35.

ANDRADE, R. O. B. de; Tachizawa, T.; Carvalho, A. B. de. (2000). Gestão ambiental. 2.ed. São Paulo: Makron Books.

ANPEI. (2005). Indicadores Empresariais sobre Pesquisa e Desenvolvimento. http://www.anpei.org.br. [Acessed January 23, 2008].

BABBIE, E. (I999). Métodos de pesquisa de survey. Belo Horizonte: Editora da UFMG.

BORGER, F. G. (200I). Responsabilidade Social: Efeitos de atuação social na dinâmica empresarial. 254 p. TESE (Doutorado em Administração) Faculdade de Economia, administração e Contabilidade, departamento de Administração -Universidade de São Paulo, São Paulo.

BRAGA, B. (2002). Introdução à engenharia ambiental. São Paulo: Prentice Hall.

CHILD, J.; Faulkner, D. (1998). Strategies of cooperation: Managing alliances, networks and joint ventures. Oxford: Oxford University Press.

COIMBRA, J. de A.A. (1985). O outro lado do meio ambiente. São Paulo: CETESB.

ETHOS. (2006). Oficina: gestão de projetos para sustentabilidade. Conferência internacional do Instituto Ethos. http:// www.ethos.org.br. [Acessed June, 20, 2009].

ETHOS. (2006). Instituto Ethos de empresas e responsabilidade social. http://www.ethos.org.br. [Acessed May, 20, 2009].

FURTADO, J. S. (2003). Gestão com Responsabilidade Socioambiental. São Paulo. http://www.teclin.ufba.br/jsfurtado. [Acessed July, I5, 2007].

GASPAR, C.A. de F. (2006). Responsabilidade socioambiental empresarial: do conceito à prática. http://www.crescer.org. [Acessed May, 19, 2006].

KEEGAN, W.j; Green, M.c. (1999). Princípios de marketing global. São Paulo: Saraiva.

KRUGLIANSKAS, I. (1996). Tornando a pequena e média empresa competitiva. São Paulo: Instituto de Estudo Gerenciais e Editora.

ISSN: 07 I 8-2724. (http://www.jotmi.org) 
KRUGLIANSKAS, M. (2008). The Influence of corporte communication in the relationship between reputation and corporate responsability. Tese de doutorado. Universitat Autônoma de Barcelona.

MALHADAS, Z. Z. (200I). Dupla ação: conscientização e educação ambiental para a sustentabilidade. Núcleo Interdisciplinar de Meio Ambiente e Desenvolvimento da Universidade Federal do Paraná.

PINTO, L. F. G.; Prada, L. De S. (I999). Certificação agrícola socioambiental: iniciativa piloto para a cana-de-açúcar. Revista informações econômicas. São Paulo, 29, 19-29.

POLIZELLI, D. L.; Petroni, L. M.; Krulgianskas, I. (2005). Gestão ambiental nas empresas líderes do setor de telecomunicações no Brasil. Revista de Administração da Universidade de São Paulo. São Paulo, 40, 309-320.

STERN, N. (2007). The Economics of Climate Change - The Stern Review.Cambridge University Press, Cambridge, UK. 